UDC: 82-291.1 Irinej Sirmijski

Александра Смирнов Бркић

Оригиналан научни рад

Ифигенија Драганић

примљено: 28. март 2013

Универзитет у Новом Саду

прихваћено: 1. октобар 2013

Филозофски факултет

Одсек за историју

aleksandrasmirnov@gmail.com

ifigenijadraganic@yahoo.com

\title{
ЛАТИНСКА И ГРЧКА РЕДАКЦИЈА ПАСИЈЕ СВ. ИРИНЕЈА СИРМИЈСКОГ*
}

Сажетак: Пасија Св. Иринеја Сирмијског (†304) према оцени стручњака спада у ред пасија чије се језгро формирало на основу римских судских аката са процеса вођеног против првог историјски потврђеног епископа Сирмијума. Пасија је сачувана у две редакције, латинској и грчкој, на основу којих се током средњег века формирала предаја и у другим европским језицима. Реномирани италијански стручњак за рано хришћанство и патристику, Манлио Симонети, пре више од пола века, први је и једини извршио компаративну анализу текста обе редакције пасије Св. Иринеја Сирмијског. С обзиром на то да ни данас у научној литератури не постоји сагласност око Симонетијевих закључака, у овом раду се поново изложе проблематика, компаративно анализира латински и грчки текст пасије и нуде нова решења у погледу првобитног језика пасије као и односа латинске и грчке редакције.

Кључне речи: пасија Св. Иринеја Сирмијског, грчка редакција, латинска редакција, хагиографија.

При изучавању самих почетака хришћанства на простору римске Друге Паноније истраживач бива засењен обиљем списа који помињу страдања панонских мученика почетком 4. века наспрам векова ћутања како писаних тако и материјалних извора. ${ }^{1}$ Међутим, истраживач убрзо спознаје да овај примамљиви изворни фонд

\footnotetext{
* Текст је настао као фазни резултат рада на пројекту Средњовековна насеља на тлу Војводине. Историјски прочеси и догађаји (бр. 114-451-2216/2011), који финансира Покрајински секретаријат за науку Владе Аутономне Покрајине Војводине.

${ }^{1}$ На основу навода у мартирологијима и сачуваних описа страдања у Панонији, позната су нам имена 22 мученика или мученица и неколицина неименованих страдалника за веру. Иако митровачки опат Павле Милер (19. век) наводи списак од око две стотине лица страдалих у Сирмијуму 304-308. године, подаци нису историјски утемељени, вид. Радомир Прица, Хришћански мученици у Сирмијуму, Sirmium и на небу и на земљи (1700 година од страдања хришћанских мученика) (ур. Душан Познановић), Сремска Митровица 2004, 27-30.
} 
махом чини хагиографска литература (мартирологији, пасије, легенде, чуда, житија), која колико год да привлачи својим детаљним наративом, прецизним датовањима и бројним именима, представља можда један од најконтроверзнијих историјских извора сумњиве провенијенције и још дубиозније садржине, који од истраживача захтева изузетну критичност и утемељену методологију. Пасије панонских мученика (Четворице овенчаних ${ }^{2}$, Иринеја из Сирмијума, Полиона из Цибала, Синерота из Сирмијума, Квирина из Цибала) страдалих у периоду 286-308. ${ }^{3}$ године чине основ познавања ранохришћанских цркава и заједница на овом подручју.

Најпре морамо нешто рећи о пасијама као жанру, јер као историјски извори имају ограничену вредност. Њихова веродостојност зависи од могућности верификације у односу на податке из других извора (мартирологија, историографије, епиграфских сведочанстава и материјалних остатака култа мученика). Први корак ка класификацији светачке литературе дао је чувени Иполит Делеје (Hippolyte Delehaye, 1859-1941), као и смернице како критички приступити том богатом, али непоузданом и некад крајње фиктивном извору о хришћанској историји. ${ }^{4}$ Делеје списе о животима и страдањима хришћанских мученика дели на шест група на основу њихове историјске вредности. Највреднији су оригинални римски судски записници или њихови преписи (Acta martyrum), ${ }^{5}$ а потом извештаји очевидаца. Трећу групу чине описи страдања, временски не много удаљени од догађаја, и базирани на судским актима које инкорпорирају у наратив (Passiones или Gesta martyrum). Четврту групу чине књижевни састави који не користе документа (Vitae sanctorum), али се базирају на историјским догађајима. ${ }^{6}$ Последње две групе чине неаутентични наративи који су или производ књижевног стваралаштва или интенциозне кривотворине. Све групе осим прве две карактерише панегирички тон. Према Делејеовој класификацији, пасија Св. Иринеја Сирмијског спада у трећу

\footnotetext{
${ }^{2}$ Иако се не могу са сигурношћу везати за Панонију, панонско порекло овог култа свакако је легитимна хипотеза. Вид. Никола Вулић, Passio sanctorum IV coronatorum, Глас СКА 82, 1934, 1-22; Фрушкогорски мученици, Гласник Историског друштва у Новом Саду IV, 1934, 359-373; Павле Мијовић, Сирмијски скулптори и каменоресии - Quattuor coronati, Старинар XVII, 1966, 53-59; Vesna Lalošević, Problemi vezani uz mučeničku grupu Svetih Četvorice Ovjenčanih, Radovi Zavoda za hrvatsku povijest 38, sv. 1, 2006, 59-72; Darija Damjanović, O ranokršćanskoj pasiji Četvorice Ovjenčanih (Passio ss. Quattuor Coronatorum), Scrinia Slavonica 9, sv. 1, 2009, 337-350; Jovan Maksimović, Marko Maksimović, Early Christian martyrs who refused to worship the cult of Asclepius in the times of Diocletian, Acta Medico-Historica Adriatica 8, sv. 2, 2010, 239-260.

3 За наведену хронологију вид. Mirja Jarak, Ranokršćanski mučenici Panonije, 1700 godina svetih srijemskih mис̌enika, Zbornik radova međunarodnog znanstvenog simpozija (ur. Darija Damjanović), Đakovo 2004, 51-71; Martyres Pannoniae - the Chronological Position of the Pannonian Martyrs in the Course of Diocletian's Persecution, Westillyricum und Nordostitalien in der spätrömischen Zeit (hrsg. Rajko Bratož), Ljubljana 1996, 263-290.

${ }^{4}$ Hippolyte Delehaye, Les passions des martyrs et les genres littéraires, Bruxelles 1921; Les légendes hagiographiques, Bruxelles 1955; Les origines du culte des martyrs, Bruxelles 1933.

${ }^{5}$ Нажалост, још је латински хришћански песник Пруденције у својој антологији песама посвећеној мученицима ране цркве приметио да су судски записи изгубљени, јер их је наводно неки војник уништио како би спречио њихову дисеминацију. Он те фундаменталне текстове назива tenaces libelli и на основу њих је од средине 2. века стварана мартиролошка литература (Prudentius, Peristeph. I 76-77).

${ }^{6}$ Упор. Tomislav Šagi-Bunić, Povijest kršćanske literature, sv. 1, Zagreb 1976, 203-223.
} 
групу пасија, ${ }^{7}$ чије се језгро формирало на основу римских судских аката са процеса вођеног против првог историјски потврђеног епископа Сирмијума и, према мишљењу стручњака, има већу историјску вредност у односу на пасије других панонских мученика. ${ }^{8}$

Како ћемо показати, овакав суд примарно се односи на латинску редакцију пасије, јер је Иринејева пасија сачувана у две редакције, латинској и грчкој, на основу којих се током средњег века формирала предаја и у другим европским језицима. ${ }^{9}$ Она јасно кореспондира другим пасијама ове групе. Ради илустрације означићемо карактеристичне делове неких пасија Јустина Филозофа (2. век) са нагласком на карактеристичном вокабулару који налазимо и у Иринејевој пасији:

\begin{abstract}
...comprehensi Justinus, et qui cum illo erant, adducti sunt ad Romae Praesidem, Rusticum nomine. Quibus ante tribunal constitutis, Rusticus Praeses dixit Justino: Age, esto diis ipsis obediens, et Imperatoris edictis. Illi autem Justinus respondit: Nemo umquam reprehendi aut condemnari poterit, qui Salvatoris nostri Jesu Christi praeceptis obedierit... cooperante gratia Domini nostri Iesu Christi, cui gloria in saecula saeculorum. Amen.
\end{abstract}

(Acta s. Iustini et sociorum) $^{10}$

Најстаријим списом типа Acta martyrum сматрају се Дела скилитанских мученика (Acta SS. Martyrum Scilitanorum) страдалих 17. јула 180. године, како спис прецизно наводи на самом почетку. Оригинални латински спис је веома кратак, без увода и закључка карактеристичног за пасије, као и без библијских цитата који се стављају у уста мученика. ${ }^{11}$ Наводимо поједине делове ради поређења са пасијом

${ }^{7}$ О другим изворима о Иринеју Сирмијском вид. Александра Смирнов-Бркић, Писани извори о св. Иринеју Сирмијском у контексту најстарије ирквене организације Срема, Средњовековна насеља на тлу Војводине, историјски процеси и догађаји (ур. Ђура Харди), Сремска Митровица 2013, 71-96; Svetozar Ritig, Martyrologij srijemsko-pannonske metropolije, Bogoslovska smotra 2-4, 1911, 353-371; Jacques Zeiller, Les origines chrétiennes dans les provinces danubiennes de l'Empire romain, Paris 1918, Жак Зелер, Почеци хришћанства на Балкану (прев. Корнелија Никчевић), Подгорица 2005, Радомир Поповић, Рано хришћанство на Балкану пре досељења Словена, Београд 1995; Милена Милин, Пасија св. Иринеја Сирмијскога, Источник 45/46, 2003, 156-161; Владислав Поповић, Блажени Иринеј, први епископ Сирмијума, Sirmium и на небу и на земљи (1700 година од страдања хришћанских мученика) (ур. Душан Познановић), Сремска Митровица 2004, 81-86.

${ }^{8}$ Херберт Мусурило, један од савремених приређивача дела мученика, ставља Иринејеву пасију у ред најстаријих типова пасија, вид. Herbert Musurillo, The Acts of the Christian Martyrs, Oxford 1972, xliii.

9 Најстарији примерак пасије Иринеја Сирмијског на старословенском језику налази се у Ретковом зборнику (лат. Codex Suprasliensis), настао крајем 10. или почетком 11. века. Кодекс је подељен на три дела која се чувају у Народној библиотеци у Варшави, Народној библиотеци Санкт Петербурга и Народној и Универзитетској библиотеци Љубљане. Део са Иринејевом пасијом се налази у санктпетербуршком рукопису и базиран је на преводу из византијског минологија, вид. R. Abicht, Quellennachweise zum Codex Suprasliensis, Archiv für slavische Philologie 16, 1894, 140-153; Иван Добрев, Гръиките думи в Супрасълския сборник и втората редакция на старобългарските богослужебни книги, Български език 28, св. 2, 1978, 89-98.

${ }^{10}$ Florilegium Patristicum (ed. Gerardus Rauschen et alii), vol. 3, Bohn 1904, 113-119; навод према Theodore Ruinart, Acta martyrum, Ratisbone 1859, 105-107.

11 Једно време се сматрало да је један грчки рукопис оригинална верзија од које потичу све остале, вид. Hermann Usener, Acta martyrum Scilitanorum Graece edita, Bonn 1881. Најстарији рукопис је латински 
Иринеја:

Praesente bis Claudiano consulibus, xvi Kalendas Augustas, Kartagine in secretario inpositis Sperato, Nartzalo et Cittino, Donata, Secunda, Vestia, Saturniuus proconsul dixit: Potestis indulgentiam domni nostri imperatoris promereri, si ad bonam mentem redeatis... Speratus dixit. Christianus sum... Fac quod vis... Speratus iterum dixit: Christianus sum: et cum eo omnes consenserunt... Saturninus proconsul decretum ex tabella recitauit: Speratum, Nartzalum, Cittinum, Donatam, Vestiam, Secundam et ceteros ritu Christiano se uiuere confesses, quoniam oblata sibi facultate ad Romanorum morem redeundi obstinanter perseuerauerant, gladio animaduerti placet... Et ita omnes simul martyrio coronati sunt, et regnant cum Patre et Filio et Spiritu Sancto per omnia saecula saeculorum. Amen.

(Acta SS. Martyrum Scilitanorum) $^{12}$

Као што видимо, знатно је мање сличности у садржају и форми између Иринејеве пасије и дела скилитанских мученика.

\section{Рукописна традиција}

Иако се прва штампана издања тзв. Дела хришћанских мученика јављају такорећи од самог проналаска штампе, ${ }^{13}$ прво штампано издање Иринејеве пасије приредило је друштво боландиста, названо по низоземском језуити Жану Боланду (лат. Johannes Bollandus, 1596-1665), који је започео чувену едицију Acta Sanctorum. Годфрид Хеншен (Godfried Henschen, 1601-1681) и Данијел Папенброх (Daniel van Papenbroek, 1628-1714) дали су 1668. године прво критичко издање латинске и грчке редакције пасије Иринеја Сирмијског у оквиру трећег тома Acta Sanctorum за месец март. $^{14}$

Боландистичко издање латинске редакције Иринејеве пасије засновано је примарно на рукопису у оквиру Бодекеновог легендарија (Legendarium Bodecensis; око 1460), ${ }^{15}$ уништеног 1945. године. ${ }^{16}$ Међутим, на основу резултата савремене науке, данас се доводи у питање ваљаност боландистичких издања рукописа који чине Acta Sanctorum. ${ }^{17}$ Стога се првим критичким издањем латинске редакције пасије Иринеја Сирмијског по стандардима савремене науке сматра оно које је дао

текст из 9. века похрањен у библиотеци Британског музеја у Лондону (Codex Brit. Mus. 11880), вид. J. А. Robinson, Texts and studies: contributions to Biblical and Patristic literature, I/2, Cambridge 1891, 112-116.

12 Исто.

${ }^{13}$ У издањима Момбриција (око 1480) и Суријуса (16. век) није уврштена пасија Иринеја Сирмијског, вид. Boninus Mombritius, Sanctuarium seu Vitae Sanctorum, t. 1, Paris 1910 (репринт); Laurentius Surius, De probatis Sanctorum historiis, II, Köln 1570-1575 (репринт 1875).

${ }^{14}$ Acta Sanctorum (у даљем тексту AA SS) Martii, pars III, Parisiis et Romae 1865, 556-557 (латински редакција), Аpp. *23 (грчка редакција).

${ }^{15}$ Вид. Analecta Bollandiana (у даљем тексту AnBol.) 27, 1908, 295.

${ }^{16}$ Упор. AnBol. 52, 1934, 196.

${ }^{17}$ François Dolbeau, Les sources manuscrites des Acta Sanctorum et leur collecte (xviie - xviiie siècles), De Rosweyde aux Acta Sanctorum. La recherche hagiographique des Bollandistes à travers quatre siècles (éds. Robert Godding, Bernard Joassart, Xavier Lequeux, François de Vriendt), Actes du Colloque international, Bruxelles, 5 octobre 2007, Bruxelles: Société des Bollandistes 2009 (Subsidia Hagiographica 88), 105-147. 
Мабјонов ученик Теодор Ринар (Theodore Ruinart), у ком пореди манускрипте шест кодекса већег кредибилитета у односу на боландистички избор. ${ }^{18}$ Ринар процењује да је пасија настала „ех Praesidialibus Actis“ која су потом преписивана у оквиру мартирологија под датумом 25. марта у већини латинских манускрипата. ${ }^{19}$ Данас нам је познат 41 латински рукопис који је садржао или садржи пасију Иринеја Сирмијског, ${ }^{20}$ од којих је најстарији са краја 8. века чуван у Баварској државној библиотеци. $^{21}$ Поменути број рукописа сведочи да је пасија била веома распрострањена на западу. Од великог је значаја констатација да је латинска редакција пасије јединствена и води порекло од истог оригиналног текста, а бројни рукописи немају већа одступања у погледу садржаја и форме, те увек почињу са: Cum esset persecutio sub Diocletiano, а завршавају: in fluvium (у неким варијација qui) Savi (варијација nuncupatur). Martyrizatus est famulus Dei sanctus Irenceus episcopus civitatis Sirmiensium, die VIII Idus Aprilis sub Diocletiano et Maximiano imperatoribus, agente Probo Proside, regnante Domino nostro Iesu Christo cui est gloria in secula seculorum. Amen. (BHL 4466).

Професор емерит Франсоа Долбо, ${ }^{22}$ последњи издавач латинске редакције Иринејеве пасије, ${ }^{23}$ указује на мане боландистичког избора латинских рукописа, јер је Бодекенов кодекс познијег датума и са доста погрешака. ${ }^{24}$ Долбо је своје издање припремио поређењем четири најстарије групе рукописа. ${ }^{25}$ Одабир је Долбо базирао на тези да рукопис из Минхена и рукопис из Беча потичу од исте традиције, као и рукописи које је користио Ринар. Друге две групе припадају једној одвојеној грани, што се види на основу одељка пасије 3.3 где се у овом случају наводе библијски

${ }^{18}$ T. Ruinart, Acta primorum martyrum sincera et selecta, Paris 1689. Ринар је користио следеће рукописе: Codd. mss. S. Remigii Remensis (изгубљен); S. Cornelii Compendiensis (изгубљен); S. Michaelis in Periculo maris (Avranches, Bibl. mun. 167, f. 114v-115, 13. век; Ринар је користио један препис сачуван у париском рукопису ms. de Paris, B. N. F. lat. 11763); Bibliothecae Colbertinae (Paris, B.N.F. lat. 5297, f. 159v-160, 13. век); Monasterii Ursicampi (изгубљен); RR. PP. Fuliensium Parisiensium (Paris, B.N.F. lat. 17004, f. 176 rv, 13. век).

19 Осим поменутих издања вид. Daniele Farlati, Illyrici sacri tomus septimus: Ecclesia Diocletana, Antibarensis, Dyrrhachiensis et Sirmiensis, Venetia 1842, XIV, 488-489; Oscar von Gebhardt, Acta martyrum selecta. Ausgewählte Märtyreracten, und andere Urkunden aus der Verfolgungszeit der christlichen Kirche, Berlin 1902, 162-165; Herbert Musurillo, The Acts of the Christian Martyrs, Oxford 1972, 294-301; Anton Benvin, Muka Sv. Ireneja srijemskoga. Ranokršćanski portret biskupa mučenika, Diacovensia 1, 1994, 84-87.

${ }^{20}$ Списак рукописа, вид. François Dolbeau, Le dossier hagiographique d'Irénée, évêque de Sirmium, Antiquitê Tardive 7, 1999, 205-214.

${ }^{21}$ München, Bayerische Staatsbibl. Clm 4554, f. 89v-91, VIII-IX век (Benediktbeuern); публиковано у Münchener Museum 1, 1912, 194; Analecta bollandiana 114, 1996, 155-156 (= Codices latini antiquiores, $\mathrm{n}^{\circ}$ 1241).

${ }^{22}$ Nous remercions sincèrement le professeur de son conseil généreux sur les manuscrits utilisés par Bollandistes dans Acta Sanctorum pour passion d'Irénée, évêque de Sirmium.

${ }^{23}$ F. Dolbeau, Le dossier, 211.

${ }^{24}$ F. Dolbeau, Le dossier, 208-209.

${ }^{25}$ To cy: München, Bayerische Staatsbibl. Clm 4554, f. 89v-91, 8-9. век (Benediktbeuern); Torino, Bibl. naz. F. III.16, f. 31-32v, 10. век (Bobbio), вид. AnBol. 28, 1909, 432; Wien, Österreichisch Nationalbibl. 371, f. 7778v, 10. век (Salzburg); S. Michaelis in Periculo maris, Bibliothecae Colbertinae (Paris, B.N.F. lat. 5297, f. 159v-160, 13. век (Foucarmont); RR. PP. Fuliensium Parisiensium (Paris, B.N.F. lat. 17004, f. 176rv, 13. век (Feuillants); Dublin, Trin. Coll. Libr. В. 1. 16 (cat. 171), 106-108; 13. век (Jervaux), вид. AnBol. 46, $1928,85$. 
стихови из Mam. 10:37-38, док прва група на том месту цитира Mam. 10:33. Долбо је у случају супротстављености ове две групе рукописа консултовао грчку традицију, али само на основу боландистичког издања. Аутори овог рада користили су као извор латинске редакције (у даљем тексту BHL 4466), примарно Ринарово и Долбово издање, али смо сматрали неопходним да поново прегледамо и на појединим местима дамо предност минхенском рукопису (у даљем тексту Minh. MS.).

Док се латинска редакција чини тако јасном у погледу провенијенције, дистрибуције, критичке анализе текста, сасвим је другачија ситуација са грчком редакцијом пасије Иринеја Сирмијског, почевши од тога да немамо потпун попис познатих рукописа који баштине ову редакцију, ${ }^{26}$ као и да је та редакција позната у три независне гране:

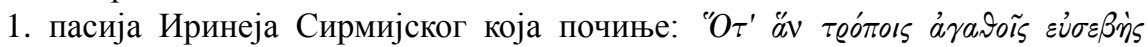

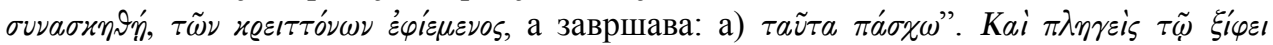

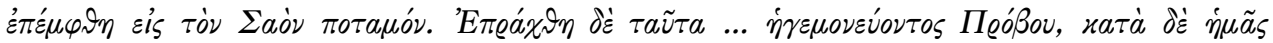

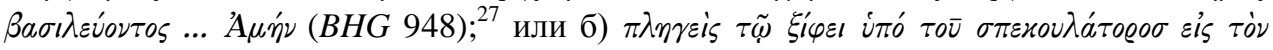

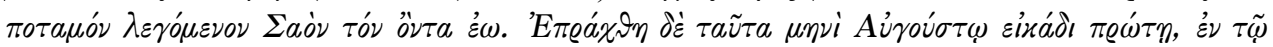

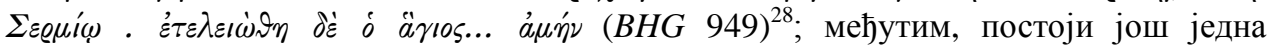

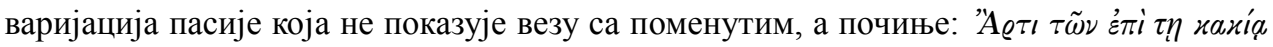

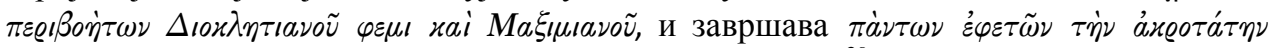

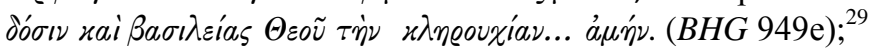

2. пасија двојице Иринеја, Сирмијског и Лионског (Passio duorum

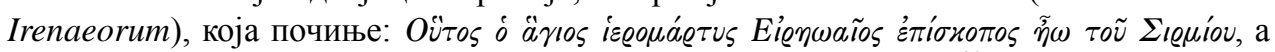

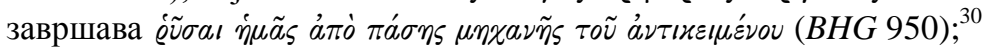

3. пасија Иринеја, Ора и Оропсеја (Passio Irenaei, Or et Oropsaei) која

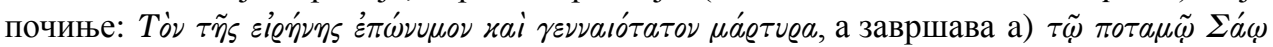

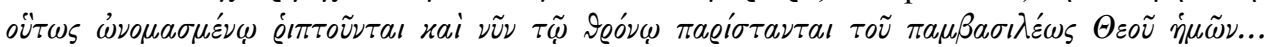

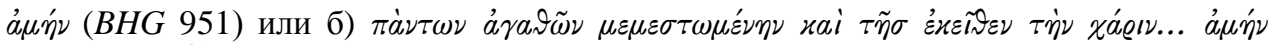
(BHG 951b). ${ }^{31}$

Као што видимо, ситуација са грчком редакцијом је знатно сложенија. Тачније, готово сва ранија истраживања Иринејеве пасије односила су се на латинску редакцију, а при помену грчке, без изузетака, мислило се на текст означен као 1а у Грчкој хагиографској библиотеции и издат код боландиста (у даљем тексту $B H G$ 948). До сада једини који је извршио компаративну анализу текста обе редакције пасије је реномирани италијански стручњак за рано хришћанство и

\footnotetext{
26 Најобухватнији је попис манускрипата грчке црквене традиције у монументалном делу Алберта Ерхарда од почетака до 16. века, вид. Albert Ehrhard, Überlieferung und Bestand der hagiographischen und homiletischen Literatur der griechischen Kirche von den Anfängen bis zum Ende des 16. Jahrhunderts, I-III, Leipzig-Berlin 1937-1952.

${ }^{27}$ Ову варијацију су објавили боландисти, вид. AA SS, Martii III, *23.

${ }^{28}$ Petrus Lambecius, Adam Franciscus Kollarius, Commentariorum de Bibliotheca Casarea Vindobonensi, VIII, Vindobonae 1782, 436-441; Упор. A. Ehrhard, Op. cit., I, 685:57.

${ }^{29}$ Ова редакција потиче од анонимног византијског минологија из 10. века, објављено у Basilius Latyšev, Menologii anonyimi byzantini saec. X quae supersunt, I, Petropoli 1912, 281-283.

${ }^{30}$ P. Lambecius, A. F. Kollarius, Op. cit., 441-442.

${ }^{31}$ B. Latyšev, Op. cit., II, 310-311.
} 
патристику, Манлио Симонети. ${ }^{32}$ Међутим, и Симонети је користио само боландистичко грчко издање ( $B H G$ 948), без увида у рукописе и варијације $B H G 949$, 950, 951, а Долбо који критикује Симонетијеве закључке као латиниста поредио је само латинске рукописе подразумевајући под грчком редакцијом исто $B H G 948$.

Стога смо сматрале нужним да поново изложимо проблематику редакција Иринејеве пасије, а затим компаративно анализирамо текст латинске и грчке редакције у свим њеним варијацијама. Такав методолошки приступ представља дуг и комплексан истраживачки рад, почев од сакупљања података о рукописима па све до анализе текста свих поменутих варијација. Овај рад показује прве фазне резултате истраживања на основу грчких редакција чије рукописе смо успеле да консултујемо до објаве рада.

Пошле смо од тога да је есенцијално које рукописе поредимо, те смо најпре испитале проблематични боландистички текст $B H G 948$ и утврдиле да се он примарно базира на рукопису који је у време првог издања (1668) носио број 174 и био чуван у тада краљевској библиотеци у Паризу (Ex MS. Regis Christianissimi Parisiis signato 174). ${ }^{33}$ Боландистички издавач објаснио је да се у свим грчким минејима за Иринејево страдање наводи 23. август, осим у рукописима минеја опатије Гротаферата (Cryptæ-ferratæ), кларомонтанског колегија, Мазаренове библиотеке и доминканског манастира у Паризу (РP. Dominicanorum reformatorum Parisiis), где је касније померен на 28. август. Иако су захваљујући Анрију Омону (1857-1940) сви фондови које је Париска национална библиотека (Bibliothèque nationale de France) крајем 19. века поседовала пописани, ${ }^{34}$ нажалост, нисмо утврдили ниједан рукопис који је у 17. веку имао нумерацију коју спомињу боландисти. Ипак, у Париској националној библиотеци налазе се следећи кодекси који садрже Иринејеву пасију: Grec 548 - раније Reg. 2481 (11. век), под 22.

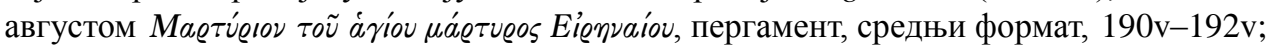
Supplément grec 241 - раније San Germanensis n. 885 (10. век), под 21. августом даје

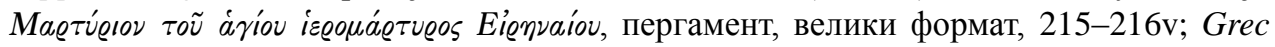

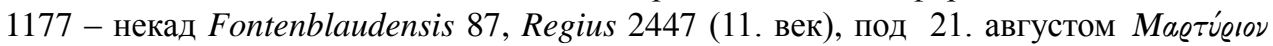

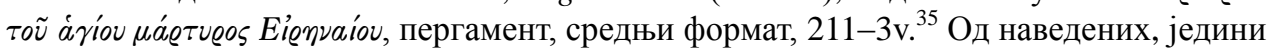
који би могао одговарати $B H G 948$ с обзиром на то да почиње истим насловом јесте последњи рукопис, али се датум не поклапа, јер су боландисти навели 23. март. Како бисмо дошле до решења, контактирале смо Париску библиотеку; а како одговор очекујемо, нова сазнања о париским рукописима Иринејеве пасије објавићемо у следећој фази истраживања.

Боландисти су користили још један грчки рукопис из Миланске библиотеке

\footnotetext{
${ }^{32}$ Manlio Simonetti, Studi agiografici, Roma 1955, 55-75.

${ }^{33}$ Paul M. Priebe, From Bibliothèque du Roi to Bibliothèque Nationale: The Creation of a State Library, 17891793, The Journal of Library History (1974-1987) 17/4, Fall 1982, 389-408.

${ }^{34}$ Henri Auguste Omont, Facsimilés des plus anciens manuscrits grecs de la Bibliotèque Nationale du IXe et XIVe siècle, Bibliothèque de l'École des chartes, Paris 1891; Facsimilés des plus anciens manuscrits grecs de la Bibliotèque Nationale du IVe et XIIIe siècle, Bibliothèque de l'École des chartes, Paris 1892; Catalogus codicum hagiographicorum graecorum Bibliothecae nationalis, Paris 1896; Catalogue des manuscrits grecs, Paris 1897. ${ }^{35}$ H. Omont, Catalogus, 108.
} 
(Biblioteca Ambrosiana), прегледом чијих фондова смо утврдили да се поменути рукопис још увек налази у њеним фондовима под истом ознаком Fol. N num. 152. ${ }^{36}$ Овај рукопис сачинио је монах по имену Laurentius у једном калабријском манастиру (,in Rutiensi Calabriæ monasterio“), како боландисти бележе: „ante annos quingentos“, дакле у 12. веку, а садржи житија светаца за месец август, укључујући

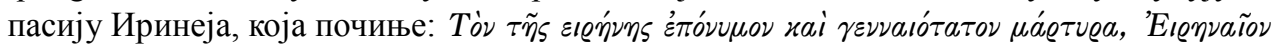

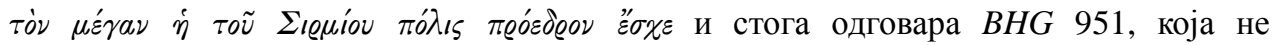
кореспондира ни са $B H G 948$ ни са $B H L 4466$.

Затим смо узели у обзир варијацију $B H G$ 949, чији се један рукопис налази у Аустријској националној библиотеци (Die Österreichische Nationalbibliothek). У овој библиотеци налази се, како ћемо показати, један од најважнијих рукописа грчке редакције пасије (Cod. Hist. Gr. 45, B1. 246r-247v). ${ }^{37}$ Рукопис потиче из 11. века и садржи минологиј за месец август у ком је под 23. августом забележена Иринејева пасија. Рукопис је за бечки двор откупио у Цариграду чувени дипломата фламанског порекла Ожије Гислен ван Бузбек (хол. Ogier Gisleen van Busbeke, лат. Augerius Gislenius Busbequius; 1522-1592). ${ }^{38}$ Бечки BHG 949 знатно је дужа и опширнија варијација $B H G 948$.

\section{Анализа текста BHL 4466, BHG 948 И $B H G 949^{39}$}

Као књижевна целина, Иринејева пасија, на основу редакција $B H L 4466$, $B H G 948$ и $B H G$ 949, може се поделити на уводну напомену састављача, опис страдања и закључну напомену. Највећу историјску вредност има централни део, који је могао настати на основу судског записника или извештаја сведока. Уводни и закључни део без сумње су накнадне примедбе састављача, при чему BHL 4466 користи 1. лице једнине (pandam/ostendam) и помиње vobis, што указује на присуство публике, у овом случају вероватно скупа верника окупљених у мартирију или базилици, што пасију чини делом литургије. ${ }^{40}$ BHG 949 и BHG 948 општим

\footnotetext{
${ }^{36}$ C. Pasini, Inventario agiografico dei manoscritti greci dell'Ambrosiana (Subsidia hagiographica 84), Bruxelles 2003.

37 Захваљујемо Одељењу за рукописе Аустријске националне библиотеке што су ауторима послали копије рукописа пасије Иринеја.

${ }_{38}$ О Бузбековој антикварној делатности вид. Ifigenija Draganić, Turciacae Epistulae: Busbecq's Views on the Power of the Ottoman Empire in his Letters, Power and Influence in South-eastern Europe: 16-19th Century (eds. Maria Baramova, Plamen Mitev, Ivan Parvev, Vania Racheva), Geschichte: Forschung und Wissenschaft, Bd. 38, Berlin 2013, 221-229.

${ }^{39}$ У анализи текстова пасије користиле смо следеће лексиконе и приручнике: Jan Frederik Niermeyer, Mediae Latinitatis Lexicon Minus, Leiden 1976; Du Cange et al., Glossarium mediae et infimae Latinitatis, 110, Niort 1883-1887; Eduard Schwyzer, Griechische Grammatik, I-II, München 1939, 1950; G. W. H. Lampe, Patristic Greek Lexicon, Oxford 1961; Charlton T. Lewis, Charles Short, A Latin Dictionary, Oxford 1879; Henry George Liddell, Robert Scott, Henry Stuart Jones, Roderick McKenzie, A Greek-English Lexicon, Oxford 1996 (9th ed.); E. A. Sophocles, Greek lexicon of the Roman and Byzantine periods (from B.C. 146 to A.D. 1100), New York 1887; Andrew L. Sihler, New Comparative Grammar of Greek and Latin, Oxford - New York 1995; Viktor Emil Gardthausen. Griechische Palaeographie, Bd. 2: Die Schrift, Unterschriften und Chronologie im Altertum und im byzantinischen Mittelalter, Leipzig 1913.

${ }^{40}$ Антон Бенвин претпоставља да је пасија у облику ком нам се сачувала писана баш за службе у
} 
неутралним тоном 3. лица говоре о мученичком примеру Иринеја. Такође поменути делови одређују историјско-географски оквир централног збивања, BHL 4466: persecutio sub Diocletiano et Maximiano imperatoribus... die VIII Idus Aprilis sub

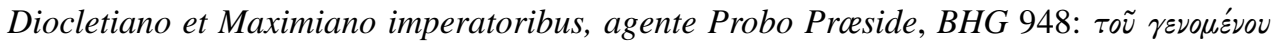

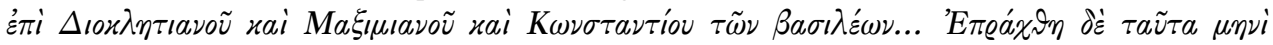

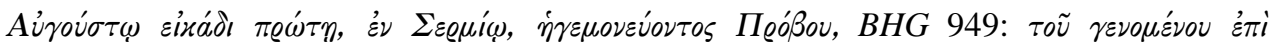

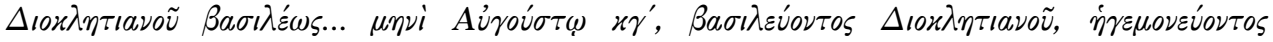
Пеóßou.

Већ у уводном делу могу се уочити значајне разлике међу рукописима латинске и грчке, као и унутар саме грчке традиције. Наиме, свака редакција различито наводи цареве у време којих се страдање одиграло. Симонети овај моменат сматра кључним у компаративној анализу пасија и утврђивању сениоритета, јер је из касније перспективе, након престанка прогона хришћана у Римском царству, Констанције, отац Константина Великог, увек у црквеној традицији приказиван као заштитник хришћана. ${ }^{41}$ Стога би његово помињање међу тзв. царевима прогонитељима могло да указује на формално навођење владара у некаквом архетипском судском процесу против Иринеја. Ипак, намеће се питање, ако је низ уобичајена хронолошка формула у којој се наводе сви тетрарси, зашто није наведен и Галерије, иначе у хришћанској традицији означен као један од виновника хришћанског прогона, а коме је у систему тетрархије припадала територија Сирмијума.

Симонетијева теза заснива се на аутентичности пасије $B H G 948$, чија је провенијенција у суштини данас непозната. Први је решење понудио учени фратар Пио Франчи де Кавалијери (1869-1960), који је сугерисао да су у првобитном оригиналу, од ког су потекле обе традиције, стајала имена све четворице тетрарха

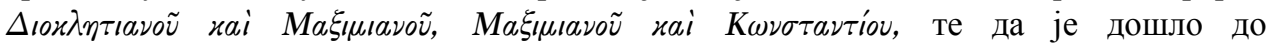
палеографске грешке познате као хомеотелеутон, где се аналогије сажимају или потиру, па су Марко Аурелије Валерије Максимијан и Гај Галерије Валерије Максимијан спојени у једну личност. ${ }^{42}$ Додајмо да је каснија црквена традиција увела пребацивање одговорности за прогоне у доба тетрархије са Диоклецијана на Галерија, па тако на пример већ мартирологиј Часног Беде код Иринеја наводи: „Еt apud Sirmium natale s. Irenaei Episcopi, qui tempore Maximiani imperatoris, sub praeside Probo, primo tormentis acerrimis vexatus, deinde diebus plurimis in carcere crucitatus, novissime abscisso capite cosummatus est“". ${ }^{43}$

Даље, уводни делови се разликују и по обиму и по садржају. Док латинска редакција почиње са веома кратким уводом коме је циљ да датује мучеништво и дефинише личност Иринеја, грчке редакције, $B H G 948$ и нарочито $B H G$ 949, знатно су китњастије, опширније и општије с циљем да изнесу парадигму понашања мученика:

\footnotetext{
сирмијским црквама које су биле посвећене Иринеју, у којима се на годишњицу мученикове смрти (лат. dies natalis) читала као део литургије, вид. А. Benvin, Op. cit., 84-87.

${ }^{41}$ M. Simonetti, Studi agiografici, 60.

${ }^{42}$ Pio Franchi de' Cavalieri, Note agiografiche, vol. 9 (Studi e Testi 175), Roma 1952, 26.

${ }^{43}$ Према S. Ritig, Op. cit., 362-363.
} 
Cum esset persecutio sub Diocletiano et Maximiano imperatoribus, quando diversis agonibus concertantes Christiani, a tyrannis illata supplicia devota deo mente suscipientes, praemiis se perpetuis participes efficiebant. Quod et factum est circa famulum dei Irenaeum episcopum urbis Sirmiensium, cuius iam nunc vobis certamen pandam victoriamque ostendam; qui pro modestia sua ingenita et timore divino cui operibus rectis inserviebat, dignus nominis sui inventus est. ${ }^{44}$

BHL 4466

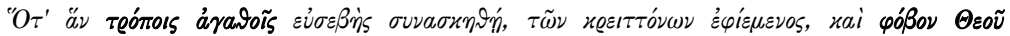

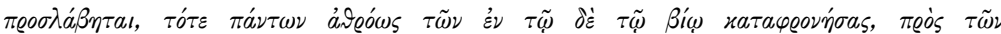

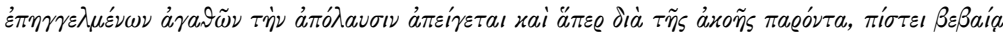

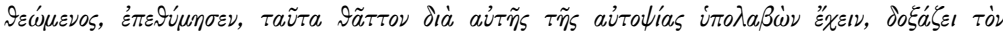
xú

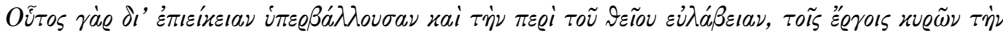

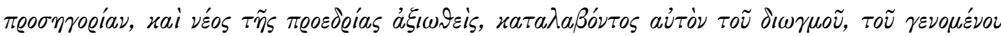

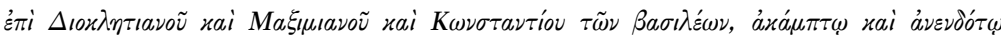

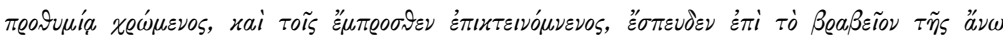
$x \lambda \dot{\eta} \sigma \varepsilon \omega \varsigma^{45}$

BHG 948

Једино што се заиста поклапа у овим преамбулама јесте име и статус Иринеја, помињање страха од Бога и исправна дела (подебљано у наводу), али у другом контексту. Симонети трвди да је латинска преамбула типична за пасије које имају грчко порекло и као пример даје увод у пасију Св. Јулија из Силистре, такође страдалог под Диоклецијаном (директне аналогије су подебљане, а индиректне подвучене):

Tempore persecutionis, quando gloriosa certamina fidelibus oblata perpetua promissa exspectabant accipere ${ }^{46}$.

Cum esset persecutio sub Diocletiano et Maximiano imperatoribus, quando diversis agonibus concertantes Christiani, a tyrannis illata supplicia devota deo mente suscipientes, praemiis se perpetuis participes efficiebant.

BHL 4466

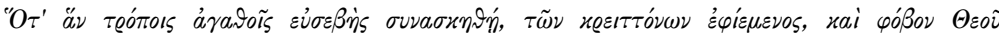

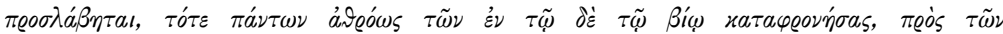

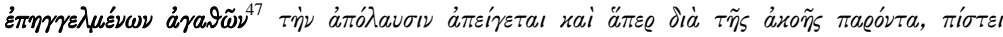

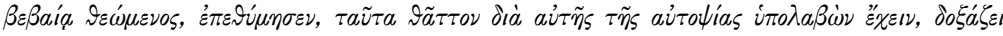

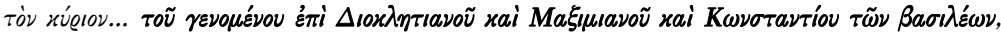

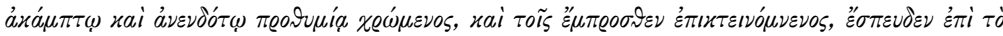

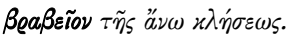

BHG 948

\footnotetext{
${ }^{44}$ F. Dolbeau, Le dossier, 211.

${ }^{45}$ AA SS, Mart. III, App. *23.

${ }^{46}$ R. Knopf, G. Krüger, Ausgewählte Märtyrerakten, Tübingen 1929, 105.

${ }^{47}$ Исто значење, али други контекст.
} 
У погледу датума Иринејевог страдања постоје следеће варијације: 25. март (VII Kal. Apr.) $)^{48}$ и 6. април (VIII Id. Apr.) ${ }^{49}$ у латинској традицији. Још већу забуну изазивају датуми у грчкој традицији где налазимо 21,22 . и 23 . август, ${ }^{50}$ док га словенски, будући на раскрсници источне и западне хришћанске традиције, бележе двојно. Датум од 25. марта резултат је конфузије између ида и календи, док је 23. август последица идентификације Иринеја Сирмијског с Иринејем Лионским, који је страдао тог датума. Година Иринејевог страдања несумњиво је пролеће 304, после прокламације 4. едикта о прогону хришћана. ${ }^{51}$ Такву хронологију потврђује уводни део пасије једног другог панонског мученика - Полиона из Цибала:

Diocletianus et Maximianus regnantes... quo tempore haec praeceptio cum venisset ad Sirmiensium civitatem; Probus Praeses imperata sibi persecutione, a clericis sumsit exordium, et comprehensum sanctum Montanum presbyterum ecclesiae Singidunensis, diuque Christianae fidei virtutibus conversatum, jussit necari. Irenaeum quoque Episcopum Sirmiensis ecclesiae, pro fide et commissae sibi plebis constantia fortiter dimicantem... 52

Садржај централног дела пасије углавном је исти. Међутим, дужина наратива се разликује, па тако текст BHL 4466, иако у преамбули краћи, у централном делу је дужи у односу на $B H G 948$ и у форми је дијалога, чиме подражава судски процес. Због дијалошке форме, која није присутна у $B H G 948$ и $B H G$ 949, истраживачи су давали примат латинској у односу на грчку редакцију. Симонети, пак, тврди да и латинска и грчка редакција коју поседујемо потичу од неког изгубљеног грчког оригинала. ${ }^{53}$ Као један од аргумената који иду у прилог првобитном грчком оригиналу Симонети наводи билингвалност подручја римске Паноније. Он даље тезу аргументује премисом да је језик раних хришћана у Сирмијуму био грчки. Мишљења о етничкој припадности првих хришћана у римској Панонији и данас су конфронтирана у научном смислу. Једни, ${ }^{54}$ судећи по броју грчких имена на хришћанским надгробним споменицима и хипотези да је на овај простор хришћанство продирало са југоистока, тврде да су први хришћани у Сирмијуму били грчког порекла. Други, ${ }^{55}$ пак, с правом тврде да је више

\footnotetext{
${ }^{48}$ AA SS, Martii III, 555.

49 Под тим датумом га помињу најстарији писани извори о Иринеју Сирмијском, Сиријски бревијар (Martyrologium syriacum) и Јеронимски мартирологиј (Martyrologium Hieronymianum), вид. AA SS, Novembris II, Bruxelles 1894, LV.

${ }^{50}$ Чувени Минологиј Василија II (Ms. Vat. gr. 1613) из 10. века наводи га 23. авуста.

${ }^{51}$ H. Musurillo, The Acts, xliii.

${ }^{52}$ Passio S. Pollionis et aliorum, према T. Ruinart, Acta martyrum, 434-436.

${ }^{53}$ M. Simonetti, Studi agiografici, 60, бел. 1. Први је идеју о грчком оригиналу изнео Тилмон, вид. L. Lenain de Tillemont, Mémoires pour servir à l'histoire ecclésiastique des six premiers siécles, t. 5, Paris 1698, 250-254. Тај став подржава и Милена Милин, вид. М. Милин, Пасија, 161. Долбо се супротставља Симонетијевом ставу сматрајући да у двојезичним срединама однос између два језика у употреби није једносмеран, те се не може утврдити који је језик примаран, F. Dolbeau, Le dossier, 206.

${ }^{54}$ Péter Kovácz, Christianity and the Greek Language in Pannonia, Acta Antiqua Hungarica 43, 2003, $113-114$.

55 М. Милин, Зачеци култова ранохришћанских мученика на тлу Србије, Култ светих на Балкану (ур. Мирјана Детелић), Крагујевац 2001, 9-24.
} 
епиграфских сведочанстава са латинским именима нарочито сирмијских хришћана, као и да се свеукупно гледано мартиролошка литература с овог подручја очувала више на латинском него на грчком језику. Такође, у најстаријим мартирологијима више је хришћанских мученика с овог подручја који носе латинска имена (Рутина, Монтан и Максима, Донат, Секунд, Кандидијан, Квирин, Полион, Ромул). Мишљења смо да се у овим судовима заборавља хронологија, јер је велика разлика у етничкој припадности сремског становништва у 5. веку, када доминира византијска администрација и грчки као служебни језик, у односу на рани 4. век, када је овде непобитно римска администрација, а један од тетрархијских дворова смештен баш у Сирмијуму.

Међутим, Симонети указује да поређењем текстова грчке и латинске редакције пасије на појединим местима могу да се уоче преводи са грчког на латински, попут iratus super fiduciam као лоше изведен превод грчког ф̊ı

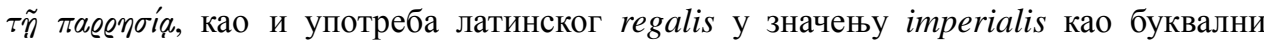

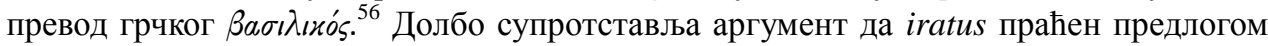
super може бити еволутивни облик класичног iratus de, а у погледу хеленизованог regalis, Долбо наводи паралелу у пасији Св. Квирина из Сисције (гл. 4, последња реченица) који нема грчку редакцију и употребу поменутог придева у пасији Св. Винсента из Сарагозе regalis decreta. ${ }^{57}$

Овде бисмо истакле још један део пасије на крају првог поглавља BHL 4466 који указује на старију грчку редакцију или барем грчког састављача пасије: dignus nomini sui inventus est, показује да је састављач тумачио грчко име Eiøпvaі̃os у значењу „миран, спокојан“.

Већу историјску вредност $B H G 948$ и $B H G 949$ би могли имати да не наводе библијске цитате које налазимо у $B H L$ 4466. Међутим, сви осим једног могу се уочити у све три редакције:

$$
\begin{array}{r}
\text { Qui diis et non Deo sacrificat eradicabitur (1 Moj 22:20 })^{58} \\
B H L 4466 \\
\text { BHG 948, BHG } 949
\end{array}
$$

Si quis me negaverit coram hominibus, et ego negabo eum coram Patre meo qui in cælis est (Мат 10:33)

BHL 4466

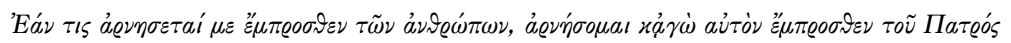

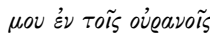
BHG 948, BHG 949

\footnotetext{
${ }^{56}$ M. Simonetti, Studi agiografici, 63.

${ }^{57}$ F. Dolbeau, Le dossier.

58 Овај библијски цитат налазимо и у другим пасијама биле оне латинског или грчког порекла, упор. пасије Петра Авесаламита, Полиона из Цибале, Филеја и Филорома, Монтана и Луција, те се може сматрати општим местом.
} 
Qui qui diligit patrem aut matrem aut uxorem aut filios aut fratres aut parentes super me, non est me dignus (Мат 10:37) ${ }^{59}$

BHL 4466

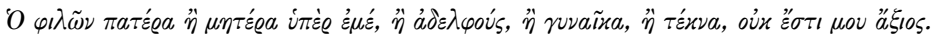
BHG 948, BHG 949

Можемо закључити да су редакције у централном делу компатибилне, али ћемо навести неколико појединости у којима се разликују. Нпр., сцена са рођацима у латинском тексту представљена је као део Пробовог испитивања, а у грчком је она на самом почетку и чак не помиње учешће намесника, већ констатује да су га рођаци молили и оплакивали. Симонети инсистира да ово место такође указује на грчко порекло латинске редакције, јер у BHL 4466 Иринеј наводно одговара Пробу на непостојеће питање: ${ }^{60}$

Et Probus ad eum dixit: Iam sacrifica, Irenaee, lucrans pœnas. Irenæus respondit: Fac quod iussum est ${ }^{61}$ vis. Hoc a me ne expectes. Probus iterum eum fustibus cædi praecipit. \| Irenaeus respondit: Deum habeo quem a prima ætate...

BHL 4466

Док је у грчком делу то донекле јасније захваљујући наративу:

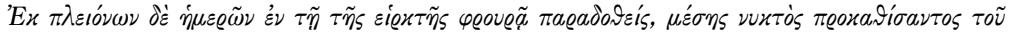

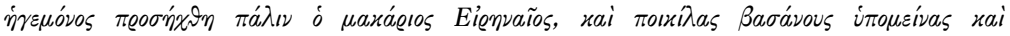

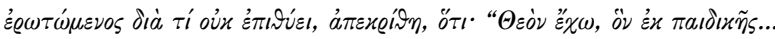

BHG 948

Ипак, најстарији латински рукопис Minh. MS. помаже у разумевању, јер за разлику од Долбоовог и Ринаровог издања иза praecipit наводи другачије читање, које је у преписима вероватно изгубљеноа:

Probus iterum eum fustibus cædi praecipit. Ille autem in medio pœnarum constitutus, dixit Irenaeus: Deum habeo quem a prima æatate...

Minh. MS

Такође, поређењем текстова $B H G 948$ и $B H G 949$ ради утврђивања њиховог међусобног односа, дошле смо до закључка да је $B H G 948$ зависан од $B H G$ 949, чиме се дискредитује његов сениоритет и по нашем мишљењу неки од Симонетијевих аргумената о грчком оригиналу Иринејеве пасије. Наиме, знатно дужи текст $B H G$ 949, захваљујући прегледу самог рукописа, помогао нам је да решимо два нејасна места у $B H G 948$ као потенцијалне грешке преписивача. У уводном делу $B H G 948$

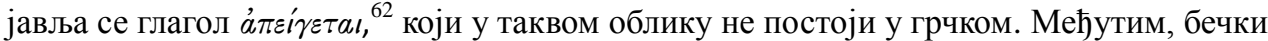

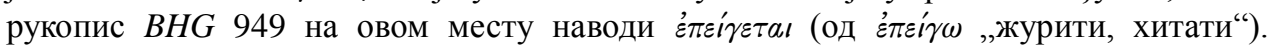

\footnotetext{
${ }^{59}$ Minh. MS. наводи Mam 10:37-38 у комбинацији са Лук 14:27: qui amat patrem aut matrem aut uxorem aut filios super me non est me dignus et qui non tollet crucem suam et sequtur me non potest meus esse discipulus.

${ }^{60}$ M. Simonetti, Studi agiografici, 66.

${ }^{61}$ Minh. MS: Fac quod iussum vis.

${ }^{62}$ E. A. Sophocles, 494.
} 


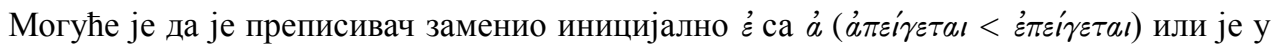

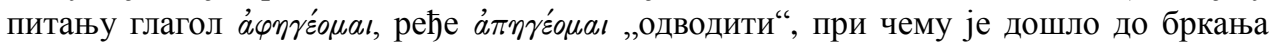

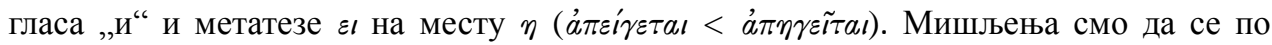

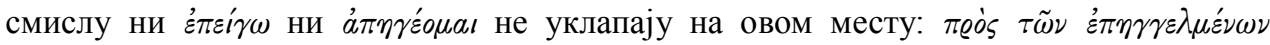

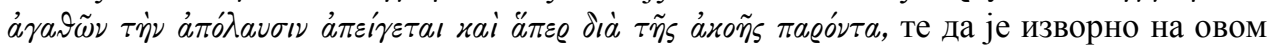

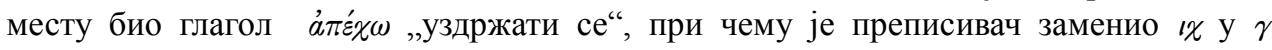

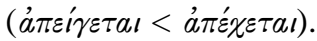

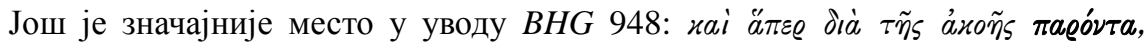

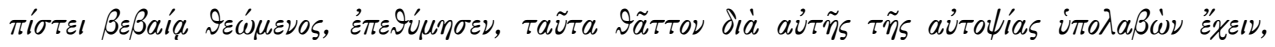

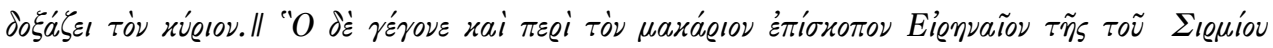

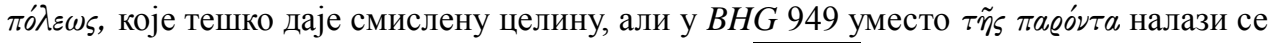

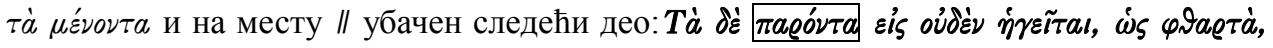

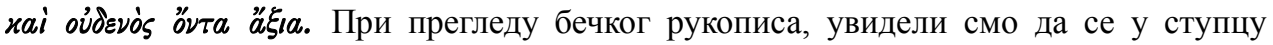

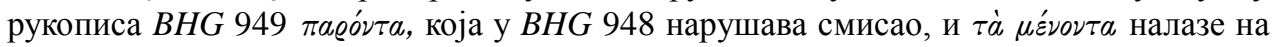
истом месту само четири реда ниже, што указује да је писац $B H G 948$ могао користити $B H G 949$ и случајно прескочити редове и опет направити грешку хомеотелеутона, или је у питању мање успешан покушај скраћивања. Нашу тезу о скраћивању $B H G 949$ која је дала $B H G 948$ донекле потврђује и поменута словенска редакција из Ретковог зборника ${ }^{63}$ пасије начињене према грчком узору. Реконструисани грчки узор још је краћи од боландистичког $B H G 948$.

Оно што по нашем мишљењу подиже историјску вредност бечког текста

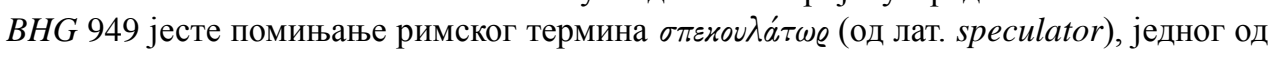
магистрата подређених провинцијском гувернеру и задуженом за егзекуције, који није касније у употреби, а не појављује се ни у BHL 4466 ни у BHG 948. Како је приметио већ Адам Франтишек Колар (18. век), царски библиотекар и историчар из доба Марије Терезије, у својим коментарима бечког рукописа пасије, боландисти су у свом издању користили „неки“ (quodam) грчки манускрипт из Париске краљевске библиотеке, али се он на више места разликује од бечког издања пасије. ${ }^{64}$

Међу разликама у редакцијама значајно место заузима име моста на коме је Иринеј погубљен, а које се у латинској редакцији BHL 4466 назива pons Basentis, ${ }^{65}$ a

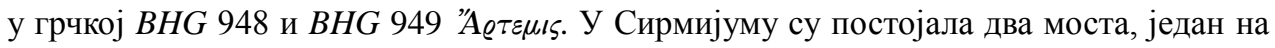
западу ка станици Ad Bassante, и други источно од града ка Сингидунуму. Раније се сматрало да је pons Basentis мост на реци Босуту (лат. Bacuntius), ${ }^{66}$ која је у римско доба имала другачији ток, те се у Саву уливала код Сирмијума. Овај податак заснивао се на етимолошкој вероватноћи као и на наводу Плинија Старијег: ,amnis Bacuntius in Saum influit, ubi civitas Sirmiensium et Amantinorum“ (Pl. N. H. III 148). Владислав Поповић хидроним Basentis везује за западни сирмијски мост и реку Босну. $^{67}$ Није решено зашто се овај мост у грчким рукописима назива Артемидин мост.

\footnotetext{
${ }^{63}$ Вид. бел. 9.

${ }^{64}$ P. Lambecius, A. F. Kollarius, Op. cit., 439.

${ }^{65}$ Постоје варијације у манускриптима: Basartas (Cod. Michaelin.).

${ }^{66}$ S. Ritig, Op. cit., 367.

${ }^{67}$ В. Поповић, Нав. дело, 81-86.
} 
Приметимо још једну значајну разлику у грчком и латинском тексту. Када Иринеј тврди да не може да се клања deos manu factos, у грчком одговара тої

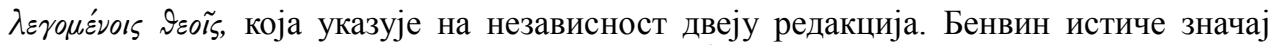
употребе глагола грчког порекла martyrizare, ${ }^{68}$ којим почиње закључни део пасије BHL 4466 Martyrizatus est који је остао „непреведен“69 у BHG 948 и BHG 949. Поменути глагол јавља се у позном латинитету, ${ }^{70}$ чијем времену одговара и састављање пасије. Овај део може бити значајан у контексту настанка латинске редакције пасије, али ниједна од сачуваних грчких редакција не садржи поменути глагол.

На крају пасије у молитви Иринеја неки рукописи наводе сирмијску цркву. Мусурило $^{71}$ и Милин ${ }^{72}$ сматрају да се молитва односила на сирмијску саборну цркву, а Долбо ${ }^{73}$ на читаву цркву, те да је придев sirmiensis накнадна интерполација. Избор речи је овде веома индикативан, јер ако је оригинални текст пасије грчки, онда би

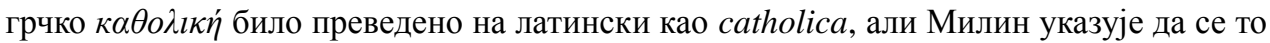
могло односити на саборну цркву као грађевину.

У погледу општих места у Иринејевој пасији, Симонети је указивао да нарочито Иринејева пасија подлеже правилима тог литерарног жанра. ${ }^{74}$ Супротно томе, Долбо истиче да ова пасија нема одлике типичног хагиографског стила, јер је настала пре формирања хагиографског клишеа 5. века. ${ }^{75}$ Валтер Бершин категоризовао је ову пасију као ,,biblischer Hintergrundstil“, 76 дакле као наратив који имитира Библију. Анализа језика пасије Иринеја показала је да она прати литерарни шаблон писма Кипријана Картагинског упућена Фортунату. ${ }^{77}$ Поред великог броја поклапања у избору библијских цитата, јавља се чак и исти редослед у том избору. Један пример је идентична комбинација библијских цитата које користи Кипријан и Иринејева пасија, на пример 2 Moj 22:20 (Fort. III.1) ${ }^{78}$ и 5 Moj 32:17 (Fort. III.1). Оваква комбинација није уобичајена међу хагиографским цитатима. Ова веза се може објаснити популарношћу Кипријановог писма Фортунату, које је дистрибуирано међу хришћанима, те је могло стићи и до самог Иринеја или састављача пасије.

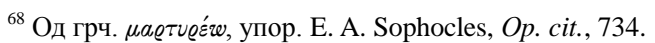

${ }^{69}$ A. Benvin, Op. cit., 93.

${ }^{70}$ J. F. Niermeyer, Op. cit., 658, према ком је глагол martyrizare први пут посведочен у делу црквеног писца 6. века Теодосија, Theodos. Itin., 2 (CSEL, t. 39, 137).

${ }^{71}$ H. Musurillo, The Acts, xlii.

${ }^{72}$ М. Милин, Пасија, 161.

${ }^{73}$ F. Dolbeau, Le dossier, 214.

${ }^{74}$ M. Simonetti, Qualche osservazione sui luoghi comuni negli atti dei martiri, Giornale italiano di filologia 10 , 1957, 147-155.

${ }^{75}$ F. Dolbeau, Op. cit., 207.

${ }^{76}$ Walter Berschin, Biographie und Epochenstil im lateinischen Mittelalter I: von der Passio Perpetuae zu den Dialogi Gregors der Großen, Quellen und Untersuchungen zur lateinischen Philologie der Mittelalters 8, Stuttgart 1986, 66-74.

${ }^{77}$ Henrik Hildebrandt, Early Christianity in Roman Pannonia - Facts among Fiction, Studia Patristica: Papers presented at the Forteenth International Conference on Patristic Studies held in Oxford 2003 (eds. F. Young, M. Edwards, P. Parvis), vol. XXXIX (Leuven-Paris-Dudley, MA 2006), 60.

${ }^{78}$ Robert Weber, Sancti Cypriani episcopi opera, vol. 1, Turnhout 1972, 181-216.
} 
Како је закључио Манлио Симонети, грчка и латинска редакција пасије Св. Иринеја „соncordano sonstalzialmente fra loro nei tratti fondamentali del racconto, ma divergono in piu di un particolare“ ${ }^{79}$ овим радом смо утврдили однос између три редакције пасије Иринеја Сирмијског означене као $B H G$ 948, BHG 949 и $B H L 4466$ као прву фазу истраживања грчке традиције пасије. Изнели смо закључак да је до сада најкоришћенија боландистичка грчка редакција $B H G 948$ базирана на рукопису још неутврђеног порекла, као и да тај рукопис представља извод из бечког $B H G 949$. Такође, сматрамо да је Симонетијев метод компаративне анализе у основи погрешан и непотпун, јер је базиран само на $B H G 948$. Симонети је закључио да су сва места која се јављају у $B H L 4466$, а не појављују у $B H G 948$, само loci commипеs који су латински преписивачи интерполирали. Међутим, он занемарује неке пасије искључиво латинске провенијенције које имају аналогија са Иринејевом, као и да је готово читава мартиролошка литература из прва 4 века заснована на случајевима из источног дела Царства, па нема правог референтног узорка на латинском да би се донео такав суд.

Извори и литература:

* Скраћенице изворних текстова су према Lampe, Patristic Greek Lexicon, Oxford 1961, a часописа и приручника према Siegfried Schwertner, International Glossary of abbreviations for Theology and related Subjects, Berlin 1974.

Извори:

Acta Sanctorum, Martii, pars III, Parisiis et Romae 1865.

Acta Sanctorum, Novembris II, Bruxelles 1894.

Analecta bollandiana 114, 1996.

Bayerische Staatsbibl. Clm 4554, f. 89v-91, München.

Bibliotheca Hagiographica Graeca, Bruxelles 1909.

Bibliotheca Hagiographica Latina, I (A-I), Bruxelles 1898-1899.

Codex Suprasliensis на адреси: http://suprasliensis.obdurodon.org/pages/supr126v.html

Die Österreichische Nationalbibliothek, Cod. Hist. Gr. 45, Bl. 246r-247v, Wien.

Florilegium Patristicum (ed. G. Rauschen, et alii), vol. 3, Bohn 1904.

Gebhardt, O. von, Acta martyrum selecta. Ausgewählte Märtyreracten, und andere Urkunden aus der Verfolgungszeit der christlichen Kirche, Berlin 1902.

Geyer, P., Itinera Hierosolymitana saeculi IIII-VIII, Pragae-Vindobonae 1898.

Lambecius, P., Kollarius, A. F., Commentariorum de Bibliotheca Casarea Vindobonensi, VIII, Vindobonae 1782.

Latyšev, B., Menologii anonyimi byzantini saec. X quae supersunt, I, Petropoli 1912.

Милин, М., Пасија св. Иринеја Сирмијскога, Источник 45/46, 2003.

Mombritius, B., Sanctuarium seu Vitae Sanctorum, t. 1, Paris 1910.

Münchener Museum 1, 1912.

Musurillo, X., The Acts of the Christian Martyrs, Oxford 1972.

${ }^{79}$ M. Simoneti, Studi agiografici, 55. 
Robinson, J. A., Texts and studies: contributions to Biblical and Patristic literature, I/2, Cambridge 1891.

Ruinart, T., Acta martyrum, Ratisbone 1859.

Surius, L., De probatis Sanctorum historiis, II, Köln 1570-1575 (репринт 1875).

Thomson, H. J., Prudentius, vol. I, London 1953.

Usener, H., Acta martyrum Scilitanorum Graece edita, Bonn 1881.

Weber, R., Sancti Cypriani episcopi opera, vol. 1, Turnhout 1972.

Литература:

Abicht, R., Quellennachweise zum Codex Suprasliensis, Archiv für slavische Philologie 16, 1894, 140-153.

Benvin, A., Muka Sv. Ireneja srijemskoga. Ranokršćanski portret biskupa mučenika, Diacovensia 1, 2, 1994, 82-109.

Berschin, W., Biographie und Epochenstil im lateinischen Mittelalter I: von der Passio Perpetuae $z u$ den Dialogi Gregors der Großen, Quellen und Untersuchungen zur lateinischen Philologie der Mittelalters 8, Stuttgart 1986.

Cavalieri, P. F. de', Note agiografiche, vol. 9 (Studi e Testi 175), Roma 1952.

Du Cange et al., Glossarium mediae et infimae Latinitatis, 1-10, Niort 1883-1887.

Damjanović, D., O ranokršćanskoj pasiji Četvorice Ovjenčanih (Passio ss. Quattuor Coronatorum), Scrinia Slavonica 9, 1, 2009, 337-350.

Delehaye, H., Les passions des martyrs et les genres littéraires, Bruxelles 1921.

Delehaye, H., Les origines du culte des martyrs, Bruxelles 1933.

Delehaye, H., Les légendes hagiographiques, Bruxelles 1955.

Добрев, И., Гръиките думи в Супрасълския сборник и втората редакиия на старобългарските богослужебни книги, Български език 28, 2, 1978, 89-98.

Dolbeau, F., Le dossier hagiographique d'Irénée, évêque de Sirmium, Antiquitê Tardive 7, 1999, 205-214.

Dolbeau, F., Les sources manuscrites des Acta Sanctorum et leur collecte (xvii ${ }^{e}-x v i i i^{e}$ siècles), De Rosweyde aux Acta Sanctorum. La recherche hagiographique des Bollandistes à travers quatre siècles (éds. Robert Godding, Bernard Joassart, Xavier Lequeux, François de Vriendt), Actes du Colloque international, Bruxelles, 5 octobre 2007, Bruxelles: Société des Bollandistes 2009 (Subsidia Hagiographica 88), 105-147.

Draganić, I., Turciacae Epistulae: Busbecq's Views on the Power of the Ottoman Empire in his Letters, Power and Influence in South-eastern Europe: 16-19th Century (eds. Maria Baramova, Plamen Mitev, Ivan Parvev, Vania Racheva), Geschichte: Forschung und Wissenschaft, Bd. 38, Berlin 2013, 221-229.

Ehrhard, A., Überlieferung und Bestand der hagiographischen und homiletischen Literatur der griechischen Kirche von den Anfängen bis zum Ende des 16. Jahrhunderts, I-III, LeipzigBerlin 1937-1952.

Farlati, D., Illyrici sacri tomus septimus: Ecclesia Diocletana, Antibarensis, Dyrrhachiensis et Sirmiensis, Venetia 1842.

Gardthausen, V. E., Griechische Palaeographie, Bd. 2: Die Schrift, Unterschriften und Chronologie im Altertum und im byzantinischen Mittelalter, Leipzig 1913.

Gebhardt, O. von, Acta martyrum selecta. Ausgewählte Märtyreracten, und andere Urkunden aus der Verfolgungszeit der christlichen Kirche, Berlin 1902.

Hildebrandt, H., Early Christianity in Roman Pannonia - Facts among Fiction, Studia Patristica: Papers presented at the Forteenth International Conference on Patristic Studies held in 
Oxford 2003 (eds. F. Young, M. Edwards, P. Parvis), vol. XXXIX (Leuven-Paris-Dudley, MA 2006), 59-64.

Jarak, M., Ranokršćanski mučenici Panonije, 1700 godina svetih srijemskih mučenika (ur. Darija Damjanović), Zbornik radova međunarodnog znanstvenog simpozija, Đakovo 2004, 5171.

Jarak, M., Martyres Pannoniae - the Chronological Position of the Pannonian Martyrs in the Course of Diocletian's Persecution, Westillyricum und Nordostitalien in der spätrömischen Zeit (hrsg. Rajko Bratož), Ljubljana 1996, 263-290.

Knopf, R., Krüger, G., Ausgewählte Märtyrerakten, Tübingen 1929.

Kovácz, P., Christianity and the Greek Language in Pannonia, Acta Antiqua Hungarica 43, 2003, 113-124.

Lalošević, V., Problemi vezani uz mučeničku grupu Svetih Četvorice Ovjenčanih, Radovi Zavoda za hrvatsku povijest 38, 1, 2006, 59-72.

Lambecius, P., Kollarius, A. F., Commentariorum de Bibliotheca Ccesarea Vindobonensi, VIII, Vindobonae 1782.

Lampe, G. W. H., Patristic Greek Lexicon, Oxford 1961.

Lewis, C. T., Short, C., A Latin Dictionary, Oxford 1879.

Liddell, H. G., Scott, R., Jones H. S., McKenzie, R., A Greek-English Lexicon, Oxford 1996 (9th ed.).

Maksimović, J., Early Christian martyrs who refused to worship the cult of Asclepius in the times of Diocletian, Acta Medico-Historica Adriatica 8, 2, 2010, 239-260.

Мијовић, П., Сирмијски скулптори и каменоресци - Quattuor coronati, Старинар XVII, 1966, 53-59.

Милин, М., Зачеци култова ранохришћанских мученика на тлу Србије, Култ светих на Балкану (ур. Мирјана Детелић), Крагујевац 2001, 9-24.

Милин, М., Пасија св. Иринеја Сирмијскога, Источник 45/46, 2003, 156-161.

Musurillo, H., The Acts of the Christian Martyrs, Oxford 1972.

Niermeyer, J. F., Mediae Latinitatis Lexicon Minus, Leiden 1976.

Omont, H. A., Facsimilés des plus anciens manuscrits grecs de la Bibliotèque Nationale du IXe et XIVe siècle, Bibliothèque de l'École des chartes, Paris 1891.

Omont, H. A., Facsimilés des plus anciens manuscrits grecs de la Bibliotèque Nationale du IVe et XIIIe siècle, Bibliothèque de l'École des chartes, Paris 1892.

Omont, H. A., Catalogus codicum hagiographicorum graecorum Bibliothecae nationalis, Paris 1896; Catalogue des manuscrits grecs, Paris 1897.

Pasini, C., Inventario agiografico dei manoscritti greci dell'Ambrosiana (Subsidia hagiographica 84), Bruxelles 2003.

Поповић, В., Блажени Иринеј, први епископ Сирмијума, Sirmium и на небу и на земљи (1700 година од страдања хришћанских мученика) (ур. Душан Познановић), Сремска Митровица 2004, 81-86.

Поповић, Р., Рано хришћанство на Балкану пре досељења Словена, Београд 1995.

Priebe, P. M., From Bibliothèque du Roi to Bibliothèque Nationale: The Creation of a State Library, 1789-1793, The Journal of Library History (1974-1987) 17/4 , Fall 1982, 389-408.

Прица, Р., Хришћански мученици у Сирмијуму, Sirmium и на небу и на земљи (1700 година од страдања хришћанских мученика) (ур. Душан Познановић), Сремска Митровица 2004, 27-30.

Ritig, S., Martyrologij srijemsko-pannonske metropolije, Bogoslovska smotra 2-4, 1911, 353-371.

Robinson, J. A., Texts and studies: contributions to Biblical and Patristic literature, I/2, Cambridge 1891. 
Schwyzer, E., Griechische Grammatik, I-II, München 1939, 1950.

Sihler, A. L., New Comparative Grammar of Greek and Latin, Oxford - New York 1995.

Simonetti, M., Studi agiografici, Roma 1955.

Simonetti, M., Qualche osservazione sui luoghi comuni negli atti dei martiri, Giornale italiano di filologia 10, 1957, 147-155.

Смирнов-Бркић, А., Писани извори о св. Иринеју Сирмијском у контексту најстарије ирквене организачије Срема, Средњовековна насеља на тлу Војводине, историјски процеси и догађаји (ур. Ђура Харди), Сремска Митровица 2013, 71-96.

Sophocles, E. A., Greek lexicon of the Roman and Byzantine periods (from B.C. 146 to A.D. 1100), New York 1887.

Surius, L., De probatis Sanctorum historiis, II, Köln 1570-1575 (репринт 1875).

Šagi-Bunić, T., Povijest kršćanske literature, sv. 1, Zagreb 1976.

Tillemont, L. L. de, Mémoires pour servir à l'histoire ecclésiastique des six premiers siécles, t. 5, Paris 1698.

Вулић, Н., Passio sanctorum IV coronatorum, Глас СКА 82, 1934, 1-22.

Вулић, Н., Фрушкогорски мученищи, Гласник Историског друштва у Новом Саду IV, 1934, 359-373.

Zeiller, J., Les origines chrétiennes dans les provinces danubiennes de l'Empire romain, Paris 1918. Зелер, Ж., Почеци хришћанства на Балкану (прев. Корнелија Никчевић), Подгорица 2005. 


\title{
ALEKSANDRA SMIRNOV BRKIĆ \\ IFIGENIJA DRAGANIĆ
}

\section{LATIN AND GREEK REDACTIONS OF THE PASSIO S. IRENAEI EPISCOPI SIRMIENSIS}

\begin{abstract}
Summary
The literary core of the passion of St. Irenaeus of Sirmium $(\dagger 304)$ is believed to be originating from the original Roman court proceedings (acta proconsularia) against the first historical bishop of Sirmium. The passion is preserved in two redactions, Latin and Greek, which made the basis for transmission into other European languages during the Middle Ages. The renowned Italian scholar Manlio Simonetti was the only to conduct a comparative analysis of the two redactions, but actually without taking an insight into the manuscript tradition and the variations within the Greek redactions. Therefore, the paper reexamines the topic, conducts a more elaborate comparative analysis on a much wider selection of manuscripts and consequently promotes new solutions to the question of the original language of the passion and the relation between the two redactions.
\end{abstract}

Keywords: The Passion of St. Irenaeus of Sirmium, Greek redaction, Latin redaction, hagiography. 